\title{
IDENTIFIKASI PERSONALISASI VERBAL DAN NONVERBAL DALAM KAJIAN PERILAKU TERITORIALITAS
}

\author{
Dela Andriani ${ }^{1 *}$, Yenny Novianti ${ }^{2}$, Nanda Savira Ersa ${ }^{3}$ \\ 1*Universitas Malikussaleh, email: dela.andriani@unimal.ac.id \\ ${ }^{2}$ Universitas Malikussaleh, email: yenny.novianty@unimal.ac.id \\ ${ }^{3}$ Universitas Malikussaleh, email: nanda.savira@unimal.ac.id
}

\begin{abstract}
ABSTRAK
Penggunaan ruang yang tanpa batas pada ruang-ruang publik di Pasar Inpres Kota Lhokseumawe, berakibat pada banyaknya intervensi pada setiap ruang sehingga berpengaruh terhadap mobilitas ruang-ruang tersebut. Untuk mempertahankan teritori dari intervensi terhadap ruang-ruang ini, maka setiap pengguna/individu mempunyai cara tersendiri. Penelitian ini dititikberatkan pada penggambaran perilaku personalisasi berdasarkan reaksi nonverbal dari setiap individu/pengguna pada salah satu segmen dari Pasar Inpres Kota Lhokseumawe. Metode penelitian yang digunakan adalah metode kualitatif deskriptif yang mengacu pada pendekatan rasionalistik. Teknik pengumpulan data dengan cara observasi lapangan lalu dilakukan pemetaan perilaku manusia di dalamnya. Dari hasil analisa dan pembahasan dapat disimpulkan bahwa perilaku personalisasi yang dilakukan oleh pengguna (pedagang) pada bagian penelitian ini sangat mendominasi. Hal ini untuk menciptakan rasa aman dan nyaman sehingga pengguna tidak perlu merasa khawatir terhadap intervensi teritorinya. Selain itu, perilaku personalisasi berdasarkan reaksi nonverbal juga terlihat pada kognisi kepemilikan secara primer, sekunder dan publik.
\end{abstract}

Kata kunci: teritori, intervensi, kualitatif, deskriptif, rasionalistik

Info Artikel:

Dikirim: 29 Juli 2021; Revisi: 30 September 2021; Diterima: 2 Oktober 2021; Diterbitkan: 4 Oktober 2021

(C2021 The Author(s). Published by Arsitekno, Architecture Program, Universitas Malikussaleh, Aceh, Indonesia under the Creative Commons Attribution 4.0 International License (https://creativecommons.org/licenses/by/4.0/).

\section{PENDAHULUAN}

Teritori menurut Halim [1] adalah ruang yang dimiliki oleh individu atau perkelompok yang ditandai secara simbolik maupun secara konkrit dan dilindungi dari invasi orang lain. Brower dalam buku Altman et. al [2], memaparkan bahwa teritorialitas merupakan hubungan individu atau kelompok dengan setting fisiknya, yang dicirikan oleh rasa memiliki, dan upaya kontrol terhadap penggunaan dari interaksi yang tidak diinginkan melalui kegiatan penempatan, mekanisme defensif dan keterikatan. Personalisasi adalah sikap menandai atau klaim terhadap teritori diri sendiri [3]. Perilaku ini memberikan efek atau bisa juga tidak memberikan efek ke teritori orang lain. Kepemilikan seseorang terhadap sebuah ruang dapat diwujudkan dengan berbagai macam cara. Kepemilikan ini dilakukan oleh berbagai individu untuk melindungi teritorinya dari intervensi orang lain. Hal ini dapat diwujudkan dari perilaku "ramah" terhadap tetangga sekitar sehingga memperkecil pengawasan dan masalah yang timbul. Dilihat dari responnya, maka perilaku ini dapat dibedakan menjadi dua; pertama, tertutup, yaitu perilaku yang tidak terlihat secara fisik namun dapat dilihat secara jelas oleh orang lain misalnya persepsi, kesadaran, perhatian dan sikap; kedua, terbuka, yaitu perilaku dalam bentuk tindakan nyata [4].

Penggunaan ruang yang tanpa batas pada ruang-ruang publik di Pasar Inpres Kota Lhokseumawe (Gambar 1), berakibat pada banyaknya intervensi pada setiap ruang sehingga berpengaruh terhadap mobilitas ruang-ruang di Pasar Inpres tersebut. 


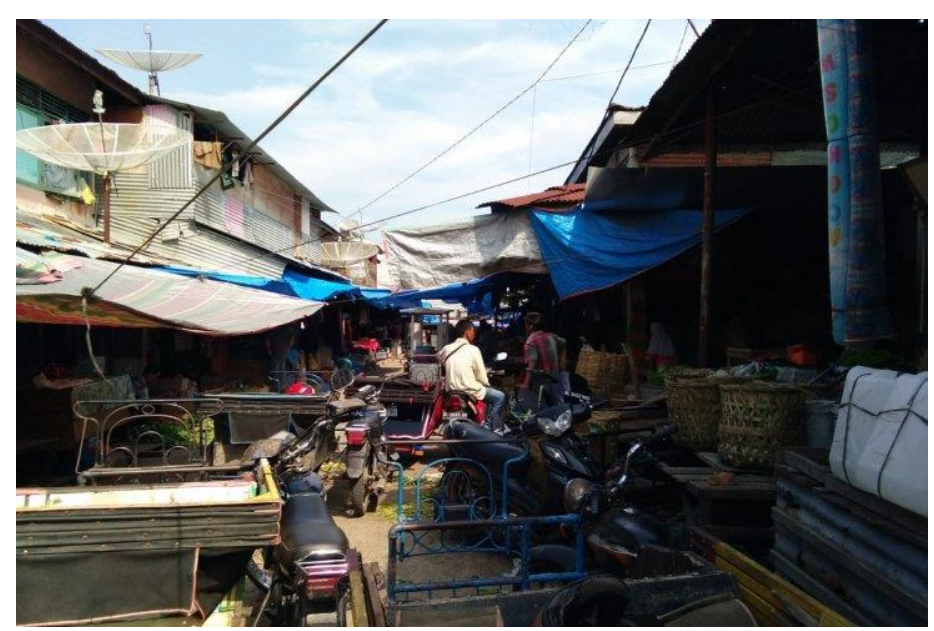

Gambar 1. Suasana Pasar Inpres Kota Lhokseumawe

Untuk mempertahankan teritori dari intervensi terhadap ruang-ruang ini, maka setiap pengguna/individu mempunyai cara tersendiri yaitu berupa perilaku nonverbal yang terlihat pada peta perilaku. Menurut Altman [5], perilaku teritori nonverbal ini terbagi menjadi 3, yaitu primer, sekunder dan publik. Berikut adalah tabel perilaku teritori berdasarkan perilaku nonverbal [6].

Tabel 1. Perilaku Teritorial Nonverbal

\begin{tabular}{ccc}
\hline Jenis Teritori & Kognisi Kepemilikan & Personalisasi/pertahanan jika dilanggar \\
\hline $\begin{array}{c}\text { Primer } \\
\text { (misalnya }\end{array}$ & $\begin{array}{c}\text { Tinggi. Dipahami sebagai milik } \\
\text { permanen baik oleh penghuni } \\
\text { rumah, kantor) }\end{array}$ & $\begin{array}{c}\text { Dipersonalisasi secara ekstensif. Pemilik } \\
\text { memiliki kontrol lengkap dan pelanggaran } \\
\text { adalah masalah serius. }\end{array}$ \\
$\begin{array}{c}\text { Sekunder } \\
\text { (misalnya }\end{array}$ & $\begin{array}{c}\text { Sedang. Tak memiliki, orang lain } \\
\text { hanya melihat penghuni sebagai salah } \\
\text { ruang kelas) }\end{array}$ & $\begin{array}{c}\text { Personalisasi selama periode yang legal. } \\
\text { Adanya aturan yang menyatakan penghuni } \\
\text { berhak mendudukinya. }\end{array}$ \\
$\begin{array}{c}\text { Publik } \\
\text { (misalnya }\end{array}$ & $\begin{array}{c}\text { Rendah. Kontrol sangat sulit } \\
\text { dilakukan, pengguna hanya dilihat } \\
\text { pantai) }\end{array}$ & $\begin{array}{c}\text { Dipersonalisasi secara temporer. Sedikit } \\
\text { sebagai salah satu dari banyaknya } \\
\text { pengguna. }\end{array}$ \\
\end{tabular}

Penelitian ini dititikberatkan pada penggambaran perilaku personalisasi berdasarkan reaksi nonverbal dari setiap individu/pengguna pada salah satu segmen dari Pasar Inpres Kota Lhokseumawe. Adapun tujuan dari penelitian ini adalah melihat pengaruh intervensi ruang pada Pasar Inpres Kota Lhokseumawe serta perilaku personalisasi berdasarkan teori teritorialitas yang dilakukan oleh pengguna di dalamnya untuk melindungi teritorinya.

\section{METODE PENELITIAN}

Metode penelitian yang digunakan adalah metode kualitatif deskriptif yang mengacu pada pendekatan rasionalistik. Kualitatif deskriptif adalah sebuah metode penelitian untuk melihat fenomena yang terjadi sehingga menghasilkan akumulasi data. Sementara pendekatan rasionalistik merupakan pendekatan untuk melihat problematika yang ada kemudian diteliti [7]. Teknik pengumpulan data dengan cara observasi lapangan lalu dilakukan pemetaan perilaku manusia yang ada di dalamnya [8]. Semua perilaku yang terkait dengan teori yaitu personalisasi berdasarkan reaksi nonverbal akan didata pada waktu-waktu tertentu ketika pengunjung sedang ramai. Pendataan dilakukan dengan cara merekam dan menggambar keadaan lokasi. Selain itu juga dilakukan penyebaran angket (kuisioner) untuk mendata perilaku apa saja yang dilakukan oleh pengguna untuk "mengamankan" teritorinya. Setelah pendataan, selanjutnya dilakukan rekap data kuisioner dan penggambaran perilaku (mapping). Dari hasil data ini, maka dilakukan analisa berdasarkan teori personalisasi lalu diambil kesimpulan dari pembahasan yang sudah ada. 


\section{PERILAKU PERSONALISASI DAN NONVERBAL PASAR INPRES KOTA LHOKSUEMAWE}

Setting adalah bagian dari model komponen, mulai dari skala ruang hingga kepercayaan [9]. Setting pada penelitian ini terletak di Pasar Inpres Kota Lhokseumawe. Pasar Inpres Kota Lhoksumawe adalah salah satu pasar tradisional yang ada di Lhokseumawe, tepatnya di Jalan Listrik (depan Kantor Pegadaian Kota Lhokseumawe), Lhokseumawe, Aceh, Indonesia. Di sini disuguhkan berbagai macam dagangan kebutuhan pokok dan sembako dengan harga murah. Sehingga pasar ini menjadi pasar teramai di Lhoksumawe.

Site yang diambil pada penelitian ini adalah salah satu segmen (bagian) Pasar Inpres Kota Lhokseumawe yang dianggap mempunyai aktivitas yang tinggi. Jumlah pedagang pada bagian ini adalah 18 pedagang. Berdasarkan teori Altman, perilaku teritori terbagi menjadi tiga, yaitu primer, sekunder dan publik. 9 pedagang berada pada teritori primer, sedangkan 9 pedagang lagi berada di teritori sekunder.
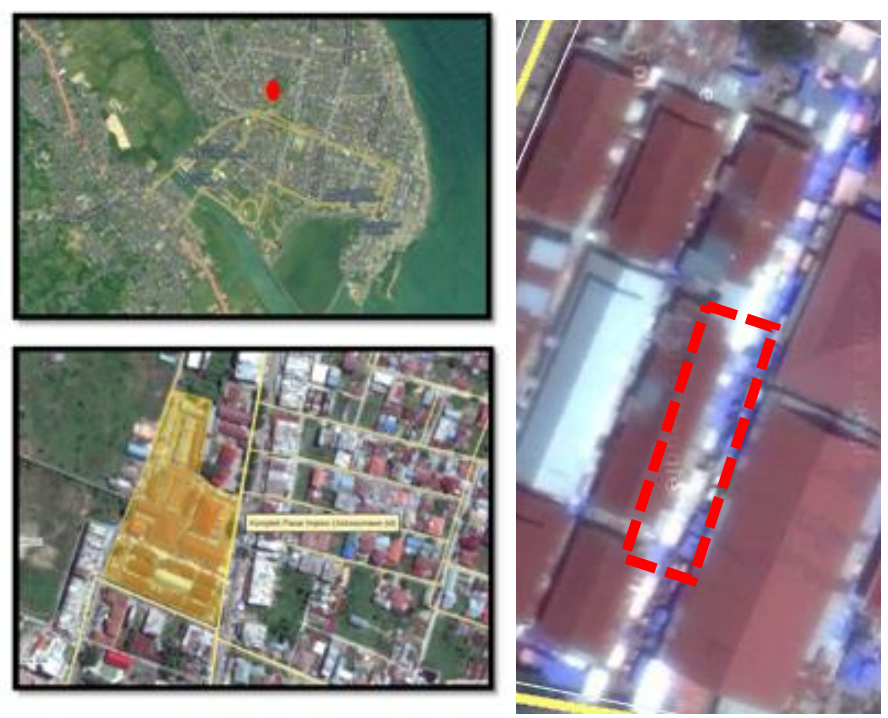

Gambar 2. Peta Lokasi

Sumber: adaptasi dari [10]

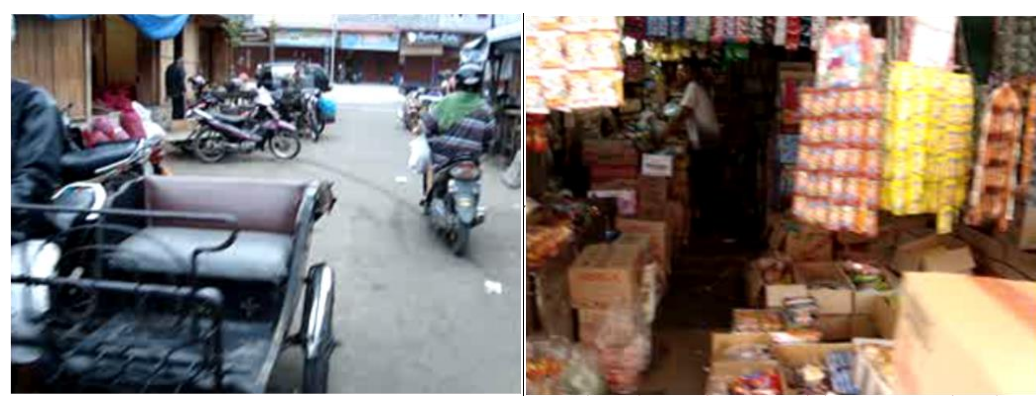

Gambar 3. Suasana Pasar Inpres Kota Lhokseumawe

Setiap individu mempunyai ruang yang menjadi mobilitasnya sehari-hari. Ruang-ruang tersebut akan dipertahankan dari intervensi siapapun. Untuk mempertahankan teritori dari intervensi terhadap ruang-ruang ini, maka setiap pengguna/individu mempunyai cara tersendiri, pertama adalah menciptakan rasa "nyaman" ketika di area teritorinya.

Berdasarkan penyebaran kuisioner terhadap pedagang pada bagian ini, maka ditemukan perilaku dalam menciptakan rasa nyaman ini yaitu dengan cara saling kenal (100\% mengenal), saling berkumpul (84\% saling berkumpul) dan saling membantu (14\% sering membantu, $59 \%$ jarang membantu). 


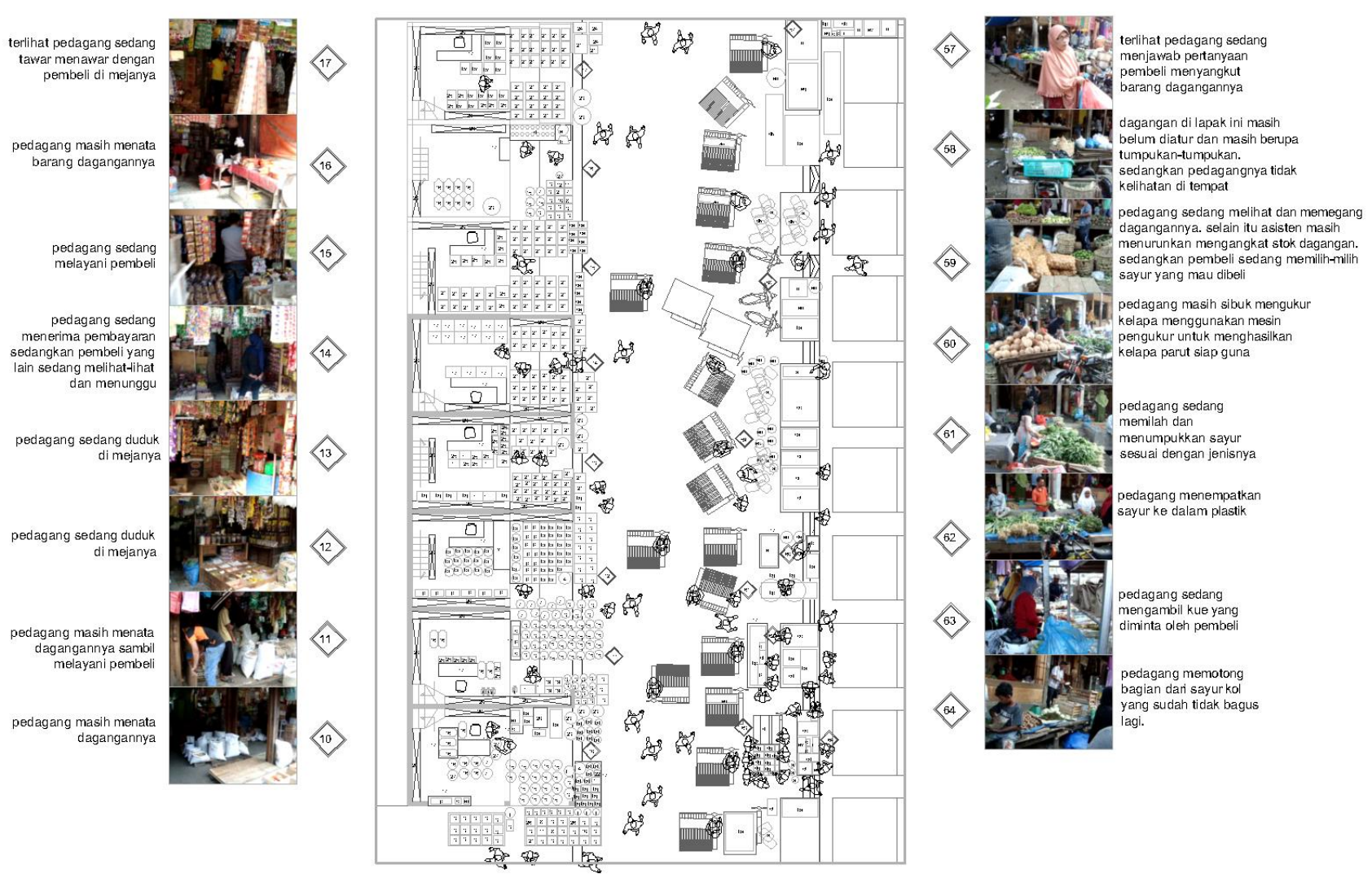

Gambar 4. Peta Perilaku Pukul 08.00-10.00 WIB
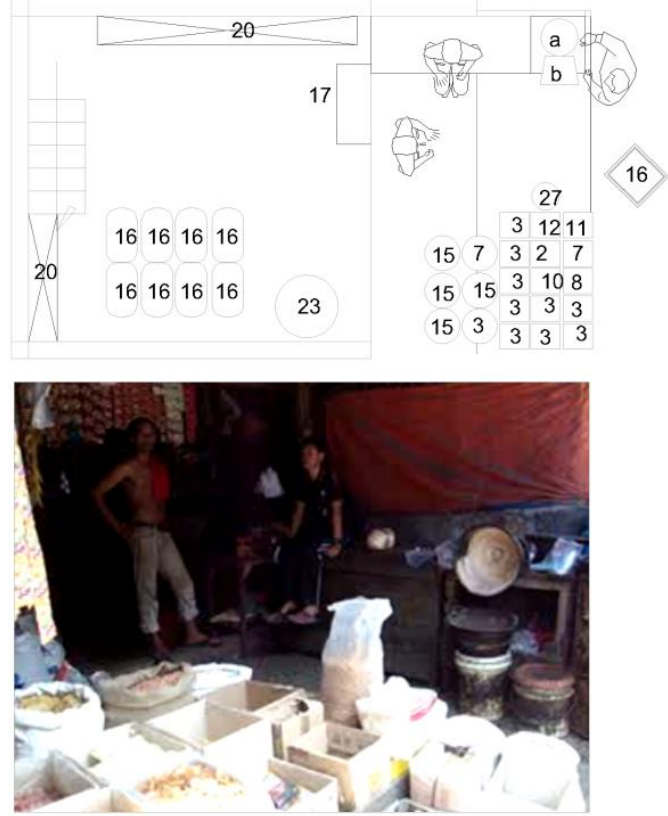

Gambar 5. Perilaku Personalisasi Saling Berkumpul

Kedua, perilaku nonverbal yang terlihat pada peta perilaku (Gambar 4). Perilaku yang dipetakan terdapat pada waktu tertentu ketika ramai pengunjung, yaitu pukul 08.00 s.d 10.00 WIB. Perilaku teritori nonverbal ini terbagi menjadi 3, yaitu primer, sekunder dan publik. Teritori primer terlihat pada fisik teritori pedagang yang bersifat permanen (Gambar 6), di mana pemilik memiliki kontrol yang lengkap dan barang siapa yang melanggar akan berada dalam masalah serius. Teritori sekunder terlihat pada pedagang yang mempunyai teritori yang tidak permanen (Gambar 7). Gambar di sebelah kiri, personalisasi teritori dilakukan dengan cara 
merapikan dagangan sambil melakukan gerakan tangan dan lengan ketika membuka dagangannya. Sementara gambar di sebelah kanan, personalisasi teritori dilakukan dengan cara menata dagangan berupa gerakan tangan dan lengan. Pedagang dipahami memiliki teritori ini mempunyai dalam periode tertentu. Sementara teritori publik, berada di luar teritori primer dan sekunder. Teritori ini berada di koridor pasar (Gambar 8).
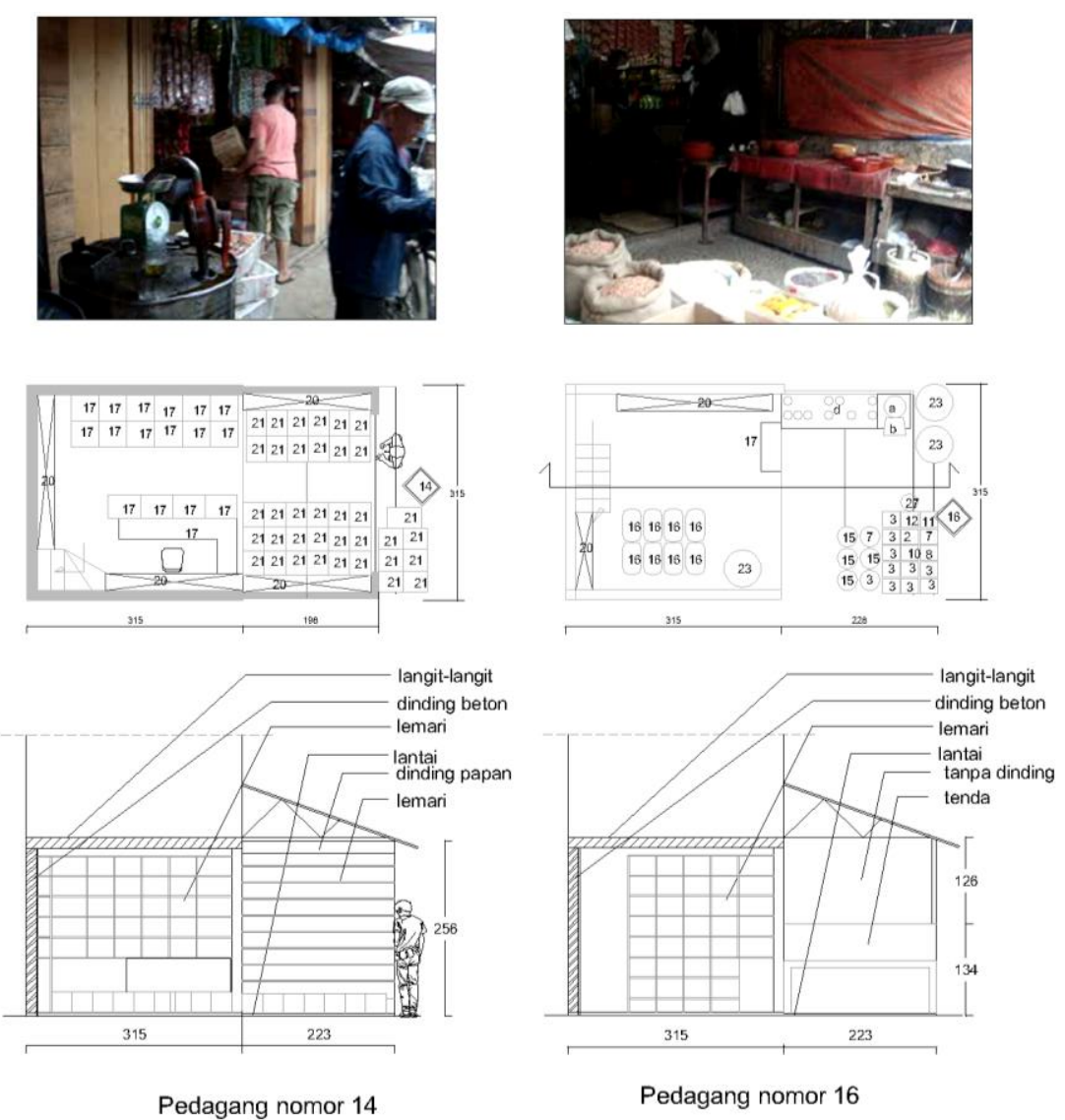

Pedagang nomor 14

Gambar 6. Teritori Primer Pedagang
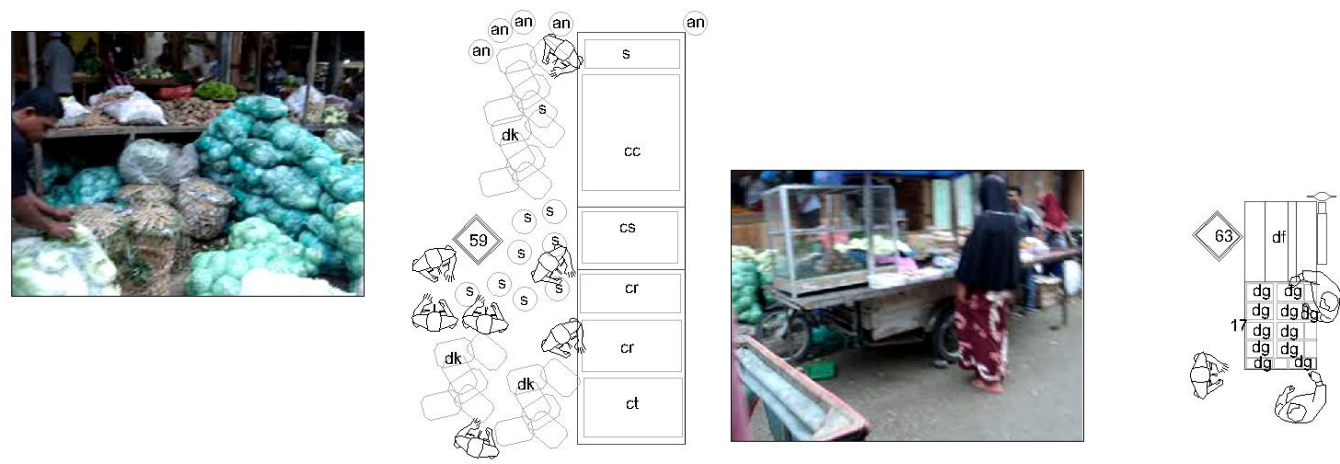

Gambar 7. Teritori Sekunder Pedagang 


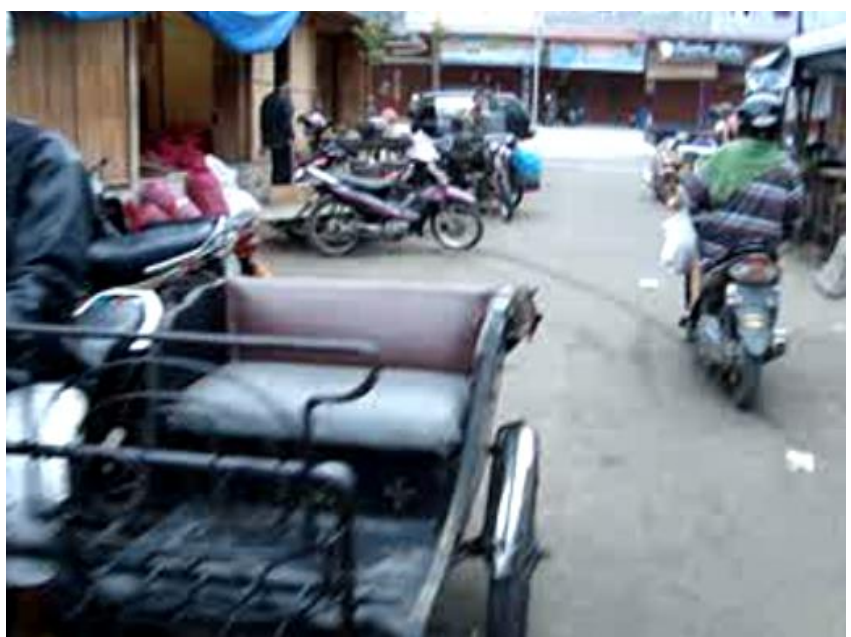

Gambar 8. Teritori publik

Sama halnya dengan perilaku tertutup dan terbuka, persepsi seseorang terhadap perilaku juga terbagi menjadi 2, yaitu faktor fisik dan psikis [11]. Berdasarkan hasil pengamatan di atas, terlihat bahwa aspek psikis berupa perhatian, dan dukungan mempengaruhi perilaku fisik yaitu penandaan dan pengawasan terhadap teritori dengan memanfaatkan media sebagai wujud dari perialaku personalisasi dalam teritorialitas. Begitu juga sebaliknya perilaku fisik akan mempengaruhi perilaku psikis.

Berdasarkan temuan-temuan di atas maka dapat disimpulkan ke dalam tabel berikut.

Tabel 2. Temuan Perilaku Personalisasi Verbal dan Nonverbal

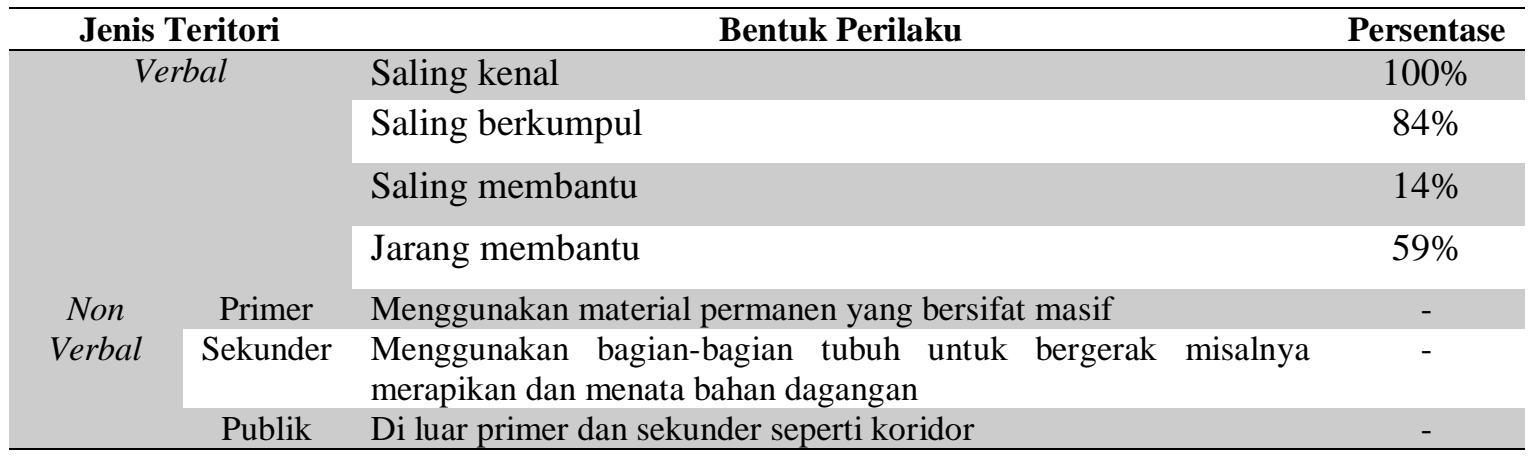

\section{KESIMPULAN}

Berdasarkan hasil pembahasan, maka dapat disimpulkan beberapa hal sebagai berikut.

a. Perilaku personalisasi terlihat pada perilaku pedagang yang saling kenal, sering berkumpul dan saling membantu. Perilaku ini akan meningkatkan rasa "aman" dan "nyaman" sehingga pemilik teritori tidak merasa khawatir akan invasi teritorinya.

b. Perilaku nonverbal pedagang terlihat pada kognisi kepemilikannya berdasarkan teritori primer, sekunder dan publik. Teritori publik bersifat permanen dan pemiliknya mempunyai kognisi yang kuat akan teritori ini. Teritori sekunder sifatnya adalah legal, namun kepemilikannya bersifat kredibel dan dalam waktu tertentu. Sementara teritori publik adalah teritori selain primer dan sekunder. Teritori ini bersifat umum dan tidak mempunyai kognisi kepemilikan.

\section{DAFTAR PUSTAKA}

[1] M. D. TODDY HENDRAWAN YUPARDHI S.Sn, "Penandaan teritori dan invasinya terhadap ruang publik," pp. 1-10, 2015.

[2] K. DI TERITORIALITAS RUANG PADA PERMUKIMAN PADAT PERKOTAAN Burhanuddin, "Karakteristik daerah teritorial pada pemukiman padat penduduk di kota," Ruang, 
vol. 2, pp. 39-46, 2010.

[3] J. Lang, "Klaim Ruang-Personalisasi-Privatisasi-Teritori \& Perilaku Teritorial,” pp. 125-143, 2010

[4] M. Prodi and A. Unsrat, “Arsitektur Berwawasan Perilaku (Behaviorisme)," Media Matrasain, vol. 8, no. 1, pp. 53-67, 2011.

[5] D. Soukotta, J. O. Waani, O. H. A. Rogi, I. Pendahuluan, and K. J. Tondano, "KLASIFIKASI RUANG TERITORI PUBLIK PADA RUMAH-RUMAH DI KAMPUNG JAWA TONDANO Studi Kasus di Lingkungan III," Media Matrasain, vol. 11, no. 2, pp. 61-67, 2014.

[6] I. D. L. HADINUGROHO, "Ruang Dan Perilaku: Suatu Kajian Arsitektural," USU Digit. Libr., no. 1973HADINUGROHO, I. D. L. (2004). RUANG DAN PERILAKU: SUATU KAJIAN ARSITEKTURAL. USU Digital Library, (1973), 1-6. Retrieved from repository.usu.ac.id/bitstream/.../1/arsitektur-dwi3.pdf, pp. 1-6, 2004, [Online]. Available: repository.usu.ac.id/bitstream/.../1/arsitektur-dwi3.pdf.

[7] B. . Wiyono, "Metodologi Penelitian." pp. 141-142, 2007.

[8] F. Kurniadi, D. Pramitasari, and D. Wijono, "Konsep Perilaku Teritorialitas di Kawasan Pasar Sudirman Pontianak," Vokasi, vol. 8, no. 3, pp. 197-208, 2012, [Online]. Available: http://riset.polnep.ac.id/bo/upload/penelitian/penerbitan_jurnal/08-Fery ganti6.pdf.

[9] P. Hendro, “Arsitektur Psikologi Dan Masyarakat.” 1998.

[10] "Google "Maps,"

2016. https://www.google.co.id/maps/@5.1833173,97.1419849,266m/data=!3m1!1e3?hl=en （accessed Oct. 03, 2021).

[11] M. P. Arsitektur et al., "MEDIA MATRASAIN," vol. 9, no. 1, pp. 58-74, 2012. 